\title{
Compound Heterozygous -30 (T>C) and Cd 41/42 (-TTCT) Leading to $\beta$ - Thalassemia Major in a Malay Autistic Patient
}

Syahzuwan Hassan ${ }^{1}$, Rahimah Ahmad ${ }^{1 *}$, Faidatul Syazlin Abdul Hamid ${ }^{1}$, Nur Aisyah Aziz ${ }^{1}$, Syahira Lazira Omar ${ }^{1}$, Siti Hida Hajira Mohamad Arif ${ }^{1}$, Intan Kartina Abdul Karim ${ }^{2}$, Thiyagar Nadarajaw ${ }^{2}$, and Zubaidah Zakaria ${ }^{1}$

${ }^{1}$ Haematology Unit, Institute for Medical Research, Jalan Pahang, 50588 Kuala Lumpur, Malaysia

${ }^{2}$ Hospital Sultanah Bahiyah, Jalan Langgar, 05460 Alor Setar, Kedah, Malaysia

"Corresponding author: Rahimah Ahmad, Haematology Unit, Institute for Medical Research, Jalan Pahang, 50588 Kuala Lumpur, Malaysia, Tel: +603-2616-2666; Fax: +603-2693-9335; E-mail: rahimah@imr.gov.my

Received date: Oct 19, 2014, Accepted date: Jan 22, 2015, Publication date: Jan 26, 2015

Copyright: (C) 2015 Hassan S, et al. This is an open-access article distributed under the terms of the Creative Commons Attribution License, which permits unrestricted use, distribution, and reproduction in any medium, provided the original author and source are credited.

\section{Abstract}

Cd 41/42 (-TTCT), IVS 1-5 (G-C), IVS 1-1 (G-T), and HbE are the most common $\beta$-globin defects among Malaysian Malays, and compound heterozygous states of the four mutations are commonly encountered. Here, we described the hematologic and DNA characterizations of our first-time encountered compound heterozygous state of $\beta^{\circ} \mathrm{Cd} 41 / 42$ (-TTCT) and a mild $\beta^{+}$TATA box mutation, $-30(T>C)$, in a Malay patient leading to $\beta$-thalassemia major. At the age of 2 , she presented with symptomatic anemia, hepatosplenomegaly, and was put on a $\beta$ thalassemia major treatment regime. Now, at the age of 6 , she was found to be autistic, a slow learner with social interaction problems, and she is under a psychiatric follow up for autism. Inevitably, the detection of $\beta$-globin defects among Malaysians must include comprehensive molecular analyses for an accurate assessment of emerging and rare mutations, as well as modifier genes affecting disease severity.

Keywords: Malay; -30 (T>C); Cd 41/42 (-TTCT); $\beta$-Thalassemia major; Spherocytosis

\section{Introduction}

Normal adult hemoglobin $(\mathrm{Hb})$ consists of two pairs of globin, two $\alpha$, and two $\beta$-chains. When the $\beta$-globin chain structure or function is altered, in which one or both copies fail to produce normal $\beta$-globin, the $\alpha$-globin gene continues its normal $\alpha$-globin production. The imbalance of $\alpha / \beta$-globin chain synthesis, most evidently in homozygous forms, leads to the accumulation of free a-globin chains, which then form highly toxic aggregates [1].

Among Malays, HbE, Cd 41/42 (-TTCT), IVS 1-1 (G>T), and IVS $1-5(\mathrm{G}>\mathrm{C})$ are the most common mutations [2]. TATA box mutations of the $\beta$-globin gene include $-28(A>G)$, as seen in Malays and Malaysian Chinese. Here, we report our first case of an uncommonly seen mutation of the TATA box, $-30(\mathrm{~T}>\mathrm{C})$, in a patient who was also compounded with the Cd 41/42 (-TTCT) mutation, resulting in $\beta$ thalassemia major.

\section{Case Report}

The proband, a 6-year-old Malay girl from a hospital in the Northern state of Malaysia, was referred to the Institute for Medical Research (IMR) with her parents' blood samples for a molecular diagnosis of $\beta$-thalassemia.

She first presented at the age of 3 years with a history of severe anemia. Her full blood count (FBC) showed an Hb level of $4.2 \mathrm{~g} / \mathrm{dL}$, and her initial full blood picture (FBP) showed hypochromic, microcytic red blood cells (RBCs) with anisopoikilocytosis. There was a predominance of spherocytes with polychromasia, and nucleated RBCs, teardrop, fragmented, and target cells were observed. A physical examination showed her liver and spleen were enlarged by 7 and 12 $\mathrm{cm}$ below the respective costal margins, respectively. An ultrasound showed these organs were homogeneous in texture, with dilated intrahepatic ducts seen in the liver. She was diagnosed as $\beta$ thalassemia major. The parents refused a splenectomy, and a fortnightly transfusion program was started, and the spleen was noted to have shrunk to $6 \mathrm{~cm}$ below the costal margin. Since diagnosis, she has received 24 blood transfusions.

At present, her growth and development is in the $10^{\text {th }}$ percentile. Her weight and height are $15.6 \mathrm{~kg}$ and $104 \mathrm{~cm}$, respectively. She is able to jump, walk, run, write the alphabet, make sentences with 2-3 words, and dress and undress herself, but she has problems interacting with other children at the kindergarten. She has been put under a psychiatric follow up for autism. She has no bone deformities, but has osteoporosis with a history of fractures documented. Cord blood searches for bone marrow transplantation (BMT) have been stopped because BMT is only eligible to patients with a related match donor. There is no plan for an Hb-augmenting agent treatment and splenectomy.

The FBC and hemoglobin analysis on the referred blood samples are shown in Table 1. The initial FBC of the proband showed low levels of $\mathrm{RBCs}$ and $\mathrm{Hb}$, as well as an increased red blood cell distribution width (RDW) percentage. The mean corpuscular volume $(\mathrm{MCV})$ and mean corpuscular hemoglobin $(\mathrm{MCH})$ were hypochromic and microcytic. The mother's hemoglobin parameters showed characteristics of typical $\beta^{\circ}$-thalassemia with elevations of RBC count and RDW, microcytic, hypochromic RBCs, and anisocytosis, as well as a reduced $\mathrm{Hb}$ content. The father's hemoglobin parameters were suggestive of a milder $\beta$-thalassemia with mild microcytosis, hypochromia RBC, anisocytosis, and elevated RDW. In addition, the $\mathrm{Hb}$ quantification by capillary electrophoresis (CE) of both parents was suggestive of a $\beta$-thalassemia trait. The maternal and paternal $\mathrm{HbA}_{2}$ were increased to 6.7 and $5.5 \%$, respectively. The impression 
drawn from both parents' peripheral blood smear studies did not detect spherocytosis. Osmotic fragility testing (OFT) on both parents was negative for hereditary spherocytosis.

\begin{tabular}{|c|c|c|c|}
\hline Parameters & Patient & Mother & Father \\
\hline Age (year)/sex & $6 / F$ & $33 / F$ & $35 / \mathrm{M}$ \\
\hline $\mathrm{Hb}(\mathrm{g} / \mathrm{dL})$ & 4.2 & 10.7 & 13.3 \\
\hline $\mathrm{RBC}\left(10^{6} / \mu \mathrm{L}\right)$ & 2.09 & 5.3 & 4.94 \\
\hline Hct (\%) & NA & 31.9 & 40.1 \\
\hline MCV (fL) & 74.0 & 60.2 & 81.2 \\
\hline $\mathrm{MCH}(\mathrm{pg})$ & 20.0 & 20.2 & 26.9 \\
\hline $\mathrm{MCHC}(\mathrm{g} / \mathrm{dL})$ & 27.1 & 33.5 & 33.2 \\
\hline RDW-CV (\%) & 31.6 & 17.61 & 14.6 \\
\hline $\mathrm{HbA}_{2}(\%)$ & 4.3 & 6.7 & 5.5 \\
\hline $\mathrm{HbF}(\%)$ & 56.3 & 1.1 & 1.1 \\
\hline \multicolumn{4}{|l|}{ Test methods } \\
\hline$\beta$-MARMS & $\begin{array}{l}\text { Cd } 41 / 42(- \\
\text { TTCT) }\end{array}$ & Cd 41/42 (-TTCT) & ND \\
\hline$\beta$-sequencing & $\begin{array}{l}-30 \quad(T>C) \\
\text { and } \\
\text { Cd } 41 / 42 \quad(- \\
\text { TTCT })\end{array}$ & NT & $-30(\mathrm{~T}>\mathrm{C})$ \\
\hline
\end{tabular}

Table 1: Haematological parameters and molecular analysis. ND- Not Detected; NT- Not Tested; NA- Not Available

The initial workup using our initial screening test for common mutations could not reveal the mutation carried by the father, while the mother and one allele of the proband were affected by the $\mathrm{Cd}$ $41 / 42$ (-TTCT) mutation. Subsequent DNA sequencing performed on the index case and the father revealed the $-30(\mathrm{~T}>\mathrm{C})$ mutation both in the father and index, as well as Cd 41/42 (-TTCT)/-30 (T>C) in the index case (Figure 1). The family tree is given in Figure 2. In addition, an $\alpha^{3.7 \mathrm{~kb}}$ and $a^{4.2 \mathrm{~kb}}$ triplication test was performed on all family members to rule out the triplication as a modifying factor, and the results were all negative.

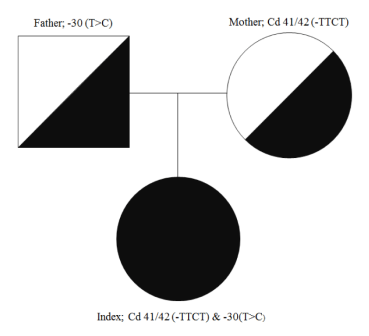

Figure 1: DNA sequencing result showing mutations of: (A) the proband with Cd 41/42 (-TTCT) (right) and -30 (T>C) (left) and (B) the father trait with $-30(\mathrm{~T}>\mathrm{C})$. The substitution changed the TATA box sequences from CATAAA to CACAAA.

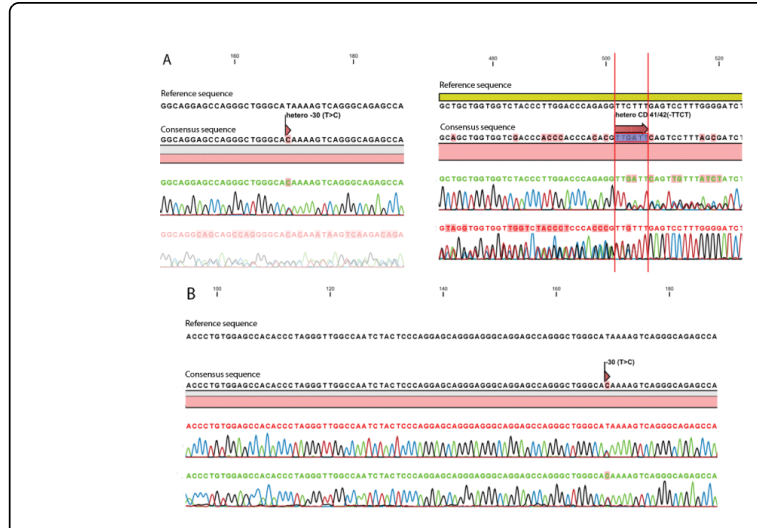

Figure 2: The family tree.

\section{Discussion}

The transcription of the globin genes is regulated by the locus control regions (LCRs) in a tissue and developmental stage-specific manner [3]. Globin production occurs by a complex interaction of LCR, transcription factors (TF), enzymes, and core promoters. The transcription of the protein-coding regions by RNA polymerase II begins with the assembly of the basal transcriptional machinery on the core promoter. The core promoter is the non-coding regions that span $\sim 100$ nucleotides proximal to the transcriptional site and distal to the coding regions, with a variable number of regulatory regions [4]. The $\beta$-globin promoters consist of a series of short functional elements interacting with transcription factors that restrict the expressions of these genes to the erythroid cells. The promoters include three cisacting elements of the TATA box, CCAAT box, and duplicated CACCC box motifs, which are necessary for efficient transcription [5].

The non-canonical TATA box (CATAAA) is located at the position -32 to -27 of the 5' Untranslated Region (5'-UTR) [6]. As well, 10 mutations within the box have been recorded by the HbVar database [7]. The most common is $-28(A>G)$, which has been recorded in Malaysian Malays and Chinese [2]. We encountered for the first time a patient affected with a common Cd 41/42 (-TTCT), compounded with a rare mutation within the highly conserved proximal promoter element: the TATA box. The nucleotide substitution was from $\mathrm{T}$ to $\mathrm{C}$ at the -30 of the $\beta$-globin gene, which was carried by the father.

Cai et al. first described the mutation during a prenatal diagnosis of a fetus with the father being a carrier of the $-30(\mathrm{~T}>\mathrm{C})$ mutation, and their first child inherited the mutation with IVS 2-654 (C>T) from the mother [8]. As well, $-30(\mathrm{~T}>\mathrm{C})$ was shown to be expressed in vitro at $30 \%$ of wild-type levels [9], indicating the mild effect of the mutation. However, in our case, her severe condition could be due to the accompanying spherocytosis.

\section{Conclusions}

We reported the first case of Cd 41/42 (-TTCT)/-30 (T>C) leading to $\beta$-thalassemia major that occurred in a Malaysian Malay autistic girl. The clinical presentation of the index patient has been described. The discovery of rare $\beta$-globin gene mutations is indicative of the heterogeneity of the mutation spectrum population. Comprehensive molecular testing using multiple methodologies is required for accurate genotyping of Malaysians with thalassemia. 
Citation: Hassan S, Ahmad R, Hamid FSA, Aziz NA, Omar SL, et al. (2015) Compound Heterozygous -30 (T>C) and Cd 41/42 (-TTCT) Leading to $\beta$-Thalassemia Major in a Malay Autistic Patient. J Blood Disorders Transf 6: 246. doi:10.4172/2155-9864.1000246

Page 3 of 3

\section{Acknowledgments}

The authors would like to thank the Director General of Health for permission to publish this case report. We would also like to thank the National Prevention and Control Program for Thalassemia Fund for supporting our efforts.

\section{References}

1. Khandros E, Thom CS, D'Souza J, Weiss MJ (2012) Integrated protein quality-control pathways regulate free $\beta$-globin in murine $\beta$-thalassemia. Blood 119: 5265-5275.

2. Hassan S, Ahmad R, Zakaria Z, Zulkafli Z, Abdullah WZ (2013) Detection of $\beta$-globin gene mutations among $\beta$-thalassaemia carriers and patients in Malaysia: Application of Multiplex Amplification Refractory Mutation System-Polymerase Chain Reaction. The Malaysian Journal of Medical Sciences 20: 13-20.

3. Grosveld F, van Assendelft GB, Greaves DR, Kollias G (1987) Positionindependent, high-level expression of the human beta-globin gene in transgenic mice. Cell 51: 975-985.
4. Baumann M, Pontiller J, Ernst W (2010) Structure and basal transcription complex of RNA polymerase II core promoters in the mammalian genome: an overview. Mol Biotech 45: 241-247.

5. Thein SL (2005) Genetic modifiers of beta-thalassemia. Haematologica 90: 649-660.

6. Wobbe CR, Struhl K (1990) Yeast and human TATA-binding proteins have nearly identical DNA sequence requirements for transcription in vitro. Mol. Cell. Biol. 10: 3859-3867.

7. Patrinos GP, Giardine B, Riemer C, Miller W, Chui DH, et al. (2004) Improvements in the HbVar database of human hemoglobin variants and thalassemia mutations for population and sequence variation studies. Nucleic acids res 32: 537-541.

8. Cai SP, Zhang JZ, Doherty M, Kan YW (1989) A new TATA box mutation detected at prenatal diagnosis for $\beta$-Thalassemia. Am. J. Hum. Genet. 45: 112-114.

9. Lewis BA, Orkin SH (1995) A functional initiator element in the human beta-globin promoter. J. Biol. Chem. 270: 28139-28144. 